\title{
STUDY OF MASS LOSSES OF CAULIFLOWER AT STORAGE DEPENDING ON A PACKING WAY
}

\author{
Ludmila Pusik \\ Department of technologies of processing of food production \\ Kharkiv Petro Vasylenko National Technical University of Agriculture \\ 44 Alchevsky str., Kharkiv, Ukraine, 61002 \\ Ludmilap@gmail.com \\ Vladimir Pusik \\ Department of Agrotechnology and Ecology \\ Kharkiv Petro Vasylenko National Technical University of Agriculture \\ 44 Alchevsky str., Kharkiv, Ukraine, 61002 \\ Vitaliy Vlasovets \\ Department of tractors and automobile \\ Kharkiv Petro Vasylenko National Technical University of Agriculture \\ 44 Alchevsky str., Kharkiv, Ukraine, 61002

\section{Ludmila Gaevaya} \\ Department of fruit and vegetable and storage \\ Kharkiv National Agrarian University named after V. V. Dokuchaev \\ Township Dokuchaevsky, Kharkiv region, Kharkiv district, Ukraine, 62483

\section{Artur Rozhkov \\ Department of Crop Production} \\ Kharkiv National Agrarian University named after V. V. Dokuchaev \\ Township Dokuchaevsky, Kharkiv region, Kharkiv district, Ukraine, 62483
}

\section{Nina Lyubymova}

Department of Forest Management and Life Safety

Kharkiv National Agrarian University named after V. V. Dokuchaev

Township Dokuchaevsky, Kharkiv region, Kharkiv district, Ukraine, 62483

\section{Iryna Safronska}

Department of management, statistics and economic analysis

Lugansk National Agrarian University

68 Slobozhanskaya str., Starobelsk, Lugansk region, Ukraine, 92703

\section{Oleksandr Romanashenko}

Department of technologies of processing of food production named after T. P. Yevsiukova

Kharkiv Petro Vasylenko National Technical University of Agriculture 44 Alchevsky str., Kharkiv, Ukraine, 61002

\section{Yevhen Kryshtop}

Department of ecology and biotechnology

Kharkiv National Agrarian University named after V. V. Dokuchaev township Dokuchaevsky, Kharkiv region, Kharkiv district, Ukraine, 62483

\section{Evgeniy Hryn}

Department of State Environmental Control of Land Resources and Subsoil State Ecological Inspectorate in Kharkiv region

5 Svobody sq., Kharkiv, Ukraine, 61022 


\begin{abstract}
Tissues of fresh vegetables are characterized by the high quantity of moisture (80..96\%), active metabolism, low resistance to mechanical lesions, are spoiled fast. Metabolism in cells of tissues, so mass losses, depends on the content of water and dry substances.

It is impossible to manage abiotic factors under conditions of open soil. So, there appears a necessity to study the influence of abiotic factors on the process of mass decrease at cauliflower storage that gives a possibility to prognosticate its mass losses and aptitude to storage.

The aim of the study was to analyze the influence of weather conditions of the vegetation period of cauliflower, volume, specific mass and porosity of heads and packing methods on the intensity of natural mass losses of cauliflower at storage. The research gives a possibility to decrease natural losses of cauliflower heads and to prolong the storage duration of it. Cauliflower mass losses at the expanse of water evaporation depend on weather conditions of the vegetation period of the plant. It has been established, that there is a middle force reverse connection with the coefficient correlation $r=-0,465$ between the intensity of water evaporation at cauliflower heads storage and GTC, middle force connection with the coefficient correlation $\mathrm{r}=0,437-$ with the average day temperature, and strong reverse connection $\mathrm{r}=-0,776$ with the relative air humidity. There was elaborated the regression equation that gives an understanding about mass losses of cauliflower heads, packed in PF, at the expanse of water evaporation.

The intensity of water evaporation of cauliflower at storage depends on package method. At packing in a stretch-film (SF), the intensity of moisture decrease, $\%$ a day, was the least, equal to $0,30-0,31$. The ratio between moisture losses to ones of dry substances was $0,45-0,68$. At packing in a performed stretch-film (PSF), the intensity of moisture decrease, $\%$ a day, was higher a little $-0,37-0,43$.

The more storage duration of cauliflower of late ripeness was provided by individual packing of heads in a polyethylene stretch-film. This packing type provided less total natural losses of products: in Skywoker $\mathrm{F}_{1}-6,0 \%$, in Kasper $\mathrm{F}_{1}$ and Santamaria $\mathrm{F}_{1}-6,3 \%$. Natural losses for a day in variants with using a stretch-film were within $0,05-0,06 \%$ depending on hybrid.

Keywords: cauliflower, weather conditions of vegetation period, mass losses, water evaporation intensity, packing way.

\title{
1. Introduction
}

Vegetables are irreplaceable component of healthy nutrition. Their value is conditioned by the presence of vitamins, mineral substances and complex of phytonutrients with an ability to neutralize free radicals [1].

Cauliflower is one of most tasty, healthy and valuable plant by the content of food substances. It is 1,5-2,0 times richer in protein, comparing with cabbage, 2-3 times - in ascorbic acid. It also predominates over cabbage by the content of mineral salts of alkaline character. The content of a dry substance is from 8,0 to $11,7 \%$. Cauliflower has a soft consistence, easily assimilated by the human organism. An important feature of this plant is in fact that fresh products are available during 6-8 months a year [2].

According to FAO [3] data in 2013, $44 \%$ of all losses of food resources are ones of fruit-vegetable products.

For keeping the quality of vegetables and for diminishing losses and waste, coordinated actions on all links of the chain from production to realization are needed. In countries with the high development level of marketing and effective after-harvesting technologies, products losses on the way from production to realization are 5-25\%. Imperfect practices of preprocessing and storage increase vegetables losses up to $20-50 \%$ [4].

The complex approach to solving the problem of supplying consumers with vegetable products with the high content of biologically active substances is in the comprehensive analysis of widening possibilities of vegetables production and storage.

The main cause of mass losses of cauliflower at storage is water losses. Cauliflower heads contain in average $80-85 \%$ of water, which part is spent for evaporation. The essential part of mass losses of fruits is connected with losses of organic substances, mainly sugars, for breathing. The 
water evaporation speed depends on a width of surface tissues, on their water-retaining capacity, unequal in different sorts.

Losses for evaporation may be diminished by two ways: decrease of saturation deficits of the environment and decrease of the moisture penetration through surface tissues of the product. Fading by $10 \%$ of an initial mass it is a limit for vegetables' life activity. After the mass loss more 9-10 \% vegetables go bad fast. The humidity in a depository doesn't remain stable. It depends on the environment humidity, storage conditions, technical possibilities. In first days of storage, when products cool down, moisture evaporation from the surface is more intensive than in following days of storage. Studies of mass losses at the expanse of water evaporation from cauliflower heads have not been realized.

The excessive transpiration negatively influences the storage quality and duration of fresh vegetables. If not to control the process of transpiration, water evaporation results in mass losses and even in formation of condensate within a package [5].

Water steam saturation is usually observed in packed fresh products. A cause is that moisture is extracted from the product, but a packing material is not enough permeable for water steam. Under such condition even unessential temperature fluctuations result in condensate [6].

At choosing a packing material, scientists recommend to use a polyethylene film, because it is elastic, stable to light, acids and alkali, easily welded, has the low water- and steam permeability, is strong and suitable for the repeated use. The modified gas environment (MGE), that contains 3-7 \% $\mathrm{CO}_{2}$ and 5-16\% $\mathrm{O}_{2}$, forms in a package of a polyethylene film with width 30-60 mcm and different holding capacities. At refrigerator storage it decelerates the development of spoilage agents, delays sprouting, decreases mass losses. The output of standard products increases by $15-30 \%$.

At individual packing, when products must be wrapped in such a way that a buyer can satisfy his/her interest maximally, a transparent polyvinylchloride stretch film is often chosen. It is very cheap and almost doesn't influence a prime cost of products. Additional information may be placed on such film (price, production place, storehouse) [7].

Studies established that a performed stretch-film is suitable for packing cauliflower, because heads in a package of non-performed one were covered by brown spots already at the third day $[8,9]$. For storing broccoli, it is recommended to choose a stretch film, because it allows to preserve organoleptic parameters of heads maximally, and A. Lucera with co-authors [10] accent attention on a fact that a performed stretch-film preserves organoleptic parameters and essentially prolongs the storage term of heads. The storage of Brussels sprouts in trays, wrapped in a stretch-film at temperature $0{ }^{\circ} \mathrm{C}$, demonstrated better results in preserving the quality at long-term storage in experiments by S. Z. Viña [11].

The aim of the study was to analyze the influence of weather conditions of the vegetation period of cauliflower, volume, specific mass and porosity of heads and packing methods on the intensity of natural mass losses of cauliflower at storage. The study gives a possibility to diminish cauliflower head losses, to differentiate and to prolong the storage duration of cauliflower.

\section{Materials and methods of studying the intensity of natural mass losses of cauliflower at storage}

The studies were conducted during 2015-2017 at an experimental field, placed in the Eastern part of the Left-Bank forest-steppe of Ukraine at the territory of Kharkiv region using drop irrigation, department of fruit and vegetable production and storage of KNAU, named after V. V. Dokuchaev.

The climate of the district, where the studies were conducted, is characterized as a moderate-continental with the unstable humidification and air temperature. The average temperature of many years, according to the meteostation of KNAU, named after V. V. Dokuchaev, is $7,2{ }^{\circ} \mathrm{C}$. January is the coldest month, its average temperature of many years is $-6,9^{\circ} \mathrm{C}$. The average annual amount of precipitation is $529 \mathrm{~mm}$, in very droughty years - 253 and to $804 \mathrm{~mm}$ - in excessively damped years. The minimal amount of precipitation is in February, the maximal - In June, July, August. The average amount of precipitation is distributed as follows: in winter $16-20 \%$, in spring 
$22-25 \%$, in summer $35-40 \%$, in autumn 35-40\%. The moisture accumulation in soil depends mainly on autumn-winter precipitation, which amount reaches $40 \%$ of annual one.

The field experiments were conducted, according to conventional methods [12]. The studies were conducted with hybrids of cauliflower of late ripeness: Skywoker $\mathrm{F}_{1}$, Santamaria $\mathrm{F}_{1}$, Kasper $\mathrm{F}_{1}$ (control - Kasper $\mathrm{F}_{1}$ ), introduced to the State Register of sorts of plants, suitable for spreading in Ukraine [13]. The term of planting seedlings is I decade of June. The planting way is seedling (seedlings with four-five real leaves were planted). The way of placing plants is band with the placing scheme $(40+100) \times 50 \mathrm{~cm}$. The density of plants is 28,6 thousand units/he. The reiteration is fourfold. The experiment is two-factor: there were studied the influence of A factor- hybrid features, B factor - vegetation period conditions. The area of each sowing plot is $21 \mathrm{~m}^{2}$. The placing of variants is systematic (Fig. 1). Standard products were laid for storage. The STANDARD EEC UNO FFV-11 Cauliflower is used in EU countries [14]. Quality parameters of cauliflower for fresh consumption in Ukraine are elucidated in SSU 3280-95«Fresh cauliflower. Technical conditions" [15], including cauliflower for realization fresh and after industrial processing. According to the standard, the most diameter of heads must be no less than $15 \mathrm{~mm}$, and heads themselves - fresh, clean, intact, healthy, without mechanical lesions, with different density degree, without damages by pests and diseases. The residue of a stalk on the cut head must be no more than $30 \mathrm{~mm}$.

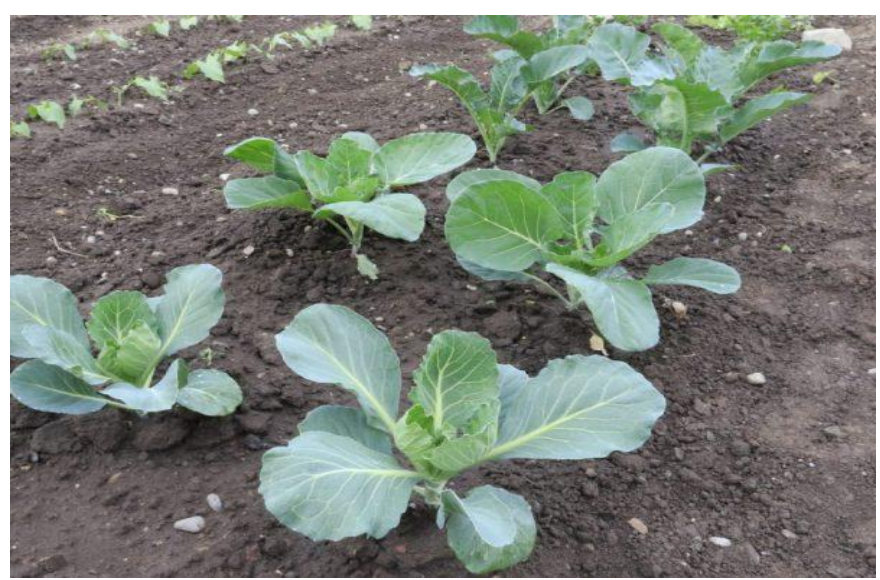

Fig. 1. Cauliflower plant

The storage was conducted according to "Methodical recommendations for storing fruits, vegetables and grape" [16]. Cauliflower was stored in the cold store Polair Standard KXH-8,81 (Russia) at temperature $0 \pm 1{ }^{\circ} \mathrm{C}$ at relative air humidity $90-95 \%$ in polymer boxes No. 6 (SS 10-15-86) [17]. The average sample mass is $4 \mathrm{~kg}$ [18].

Cauliflower heads were stored:

1) in boxes without a package - control; with a package;

2) in boxes, covered with a polyethylene film with width $40 \mathrm{mcm}$ "Polyethylene film" (SS 1354-82) [19], its edges were densely enveloped;

3) in a stretch-film PVC (polyvinylchloride) with width $8 \mathrm{mcm}$;

4) in a performed stretch-film of the same width.

The observations over cauliflower were conducted in dynamics in 10 days. Samples were taken and prepared for the analyses according to SSU ISO 874-2002 [20]. The value of natural mass losses at storage was determined by the method of fixed samples [21].

The characteristic of the studied hybrids:

Kasper $\mathbf{F}_{\mathbf{1}}$. It is an extremely enduring 85-95-day hybrid for summer and autumn planting, Fig. 2. A special feature: it is excellent at summer planting - forms heads even at high night temperatures. It easily endures high temperatures and low air humidity of Crimea and South of Ukraine without harvest worsening. It has the well-developed leaf apparatus and ideal coverage of racemes. A raceme is solid white, without fluffiness, mass $1,5-2,5 \mathrm{~kg}$. It is appropriate for usage fresh and for processing, including freezing. The recommended density is $28-35$ thousand plants for 1 he. 


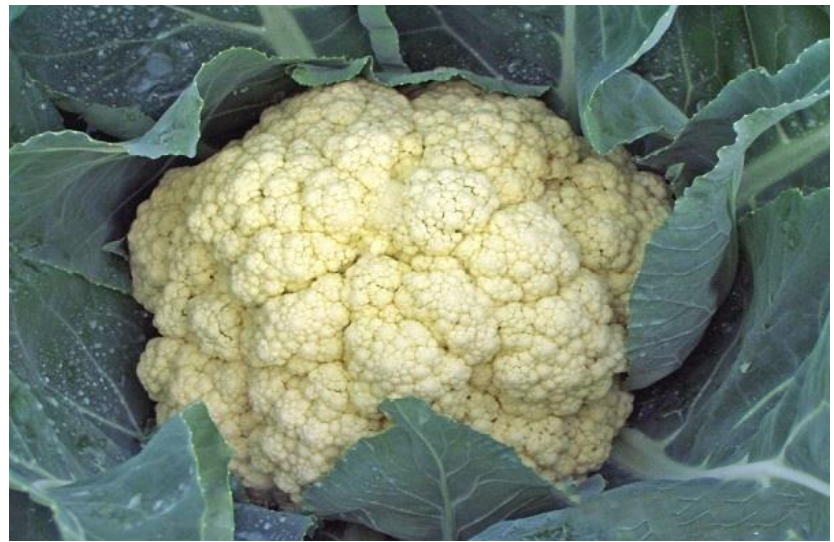

Fig. 2. Kasper $F_{1}$

Santamaria $\mathbf{F}_{1}$. It is a hybrid for all-season planting (Fig. 3). It has a good growth force, weakly reacts to the lack of calcium. It has the well-developed leaf apparatus and root system. The raceme mass is $1,5-2,5 \mathrm{~kg}$. The vegetation period is $75-95$ days. The recommended density is 28-32 thousand plants for 1 he. [22].

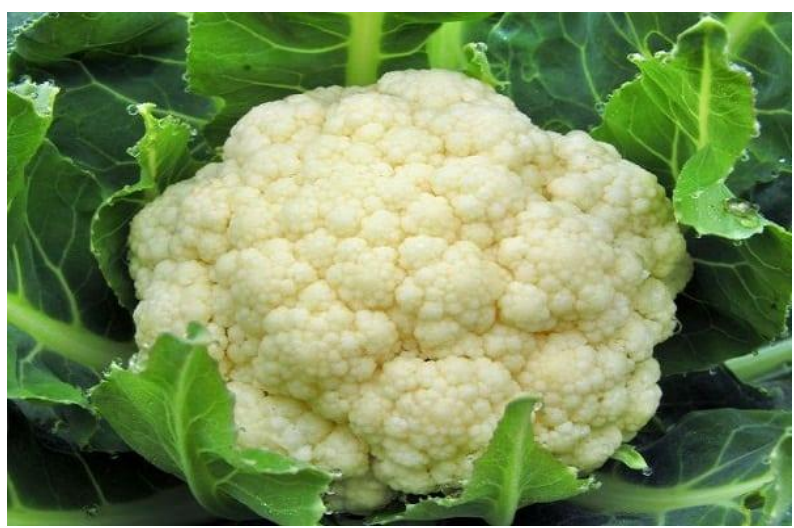

Fig. 3. Santamaria $F_{1}$

Skywoker $\mathbf{F}_{\mathbf{1}}$. It ripens in 90-95 days after seedlings planting. Heads are white, dense, well-covered by leaves, with mass $1,5-3,0 \mathrm{~kg}$, have the very pleasant commodity outlook (Fig. 4) and unique taste. The hybrid is suitable for processing, namely freezing and package, demonstrates good results at пкщцing to the ripeness. It is profitable and reliable to plant such cauliflower in winter and late autumn periods. The recommended density is 25-30 thousand plants for 1 he [23].

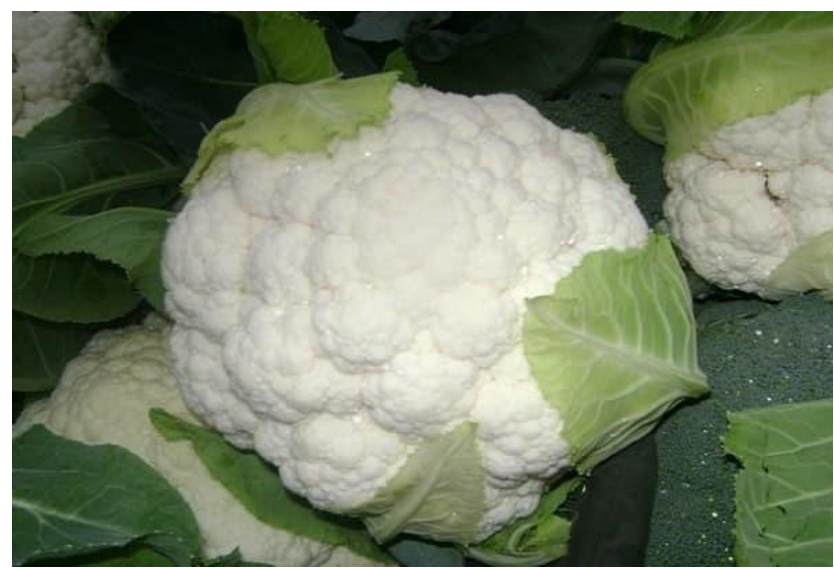

Fig. 4. Skywoker $F_{1}$ 
The characteristics of the studied packing materials:

Polyethylene film is waterproof, has the high chemical stability; it is a relatively cheap material, has a small weight, strong, provides protection from the negative influence of the environment due to package hermeticity [24]. The film with width $40 \mathrm{mcm}$ has the following physical properties at temperature $25{ }^{\circ} \mathrm{C}$ : gas permeability $-5,43 \mathrm{~cm}^{3} \mathrm{O}_{2} / \mathrm{dm}^{2}$ for 24 hours; steam permeability $-0,045 \mathrm{~g} / \mathrm{dm}^{3}$ for 24 hours; water permeability $-0,035 \mathrm{~g} / \mathrm{dm}^{3}$ for 24 hours [21].

Food polyvinylchloride (PVC) film is used as a one-off package for food products with long and short storage terms, directly or on trays. It is universal in usage, both hot and cooled, frozen products may be wrapped by it. It is used at both packing by hand and with using auxiliary devices and also on automatic machines. A food PVC stretch-film has the selective gas permeability of air components: water steam and carbon dioxide go away, oxygen comes in that provides "respiration" of a product. It prevents condensate formation; has the increased resistance to aggressive mediums and fats; good glueyness that prevents the film from unwrapping independently at packing and allows to reach hermetic package of products; increase strength and resistance to pinholes, breaks and blows that doesn't allow the film to tear at packing and storage of packed products. The stretch-film keeps high strength characteristics at low temperatures, temperature and humidity drops; it has the perfect transparency that provides a pleasant commodity outlook of the package. The film with width $8 \mathrm{mcm}$ has the gas permeability at level $9,0 \mathrm{O}_{2} / \mathrm{dm}^{2}$ for 24 hours, steam permeability $-0,05-0,068 \mathrm{~g} / \mathrm{dm}^{3}$ for 24 hours [9, 21].

During the storage, there were determined: natural mass losses, commodity quality, physical properties of heads:

- dry substances - by drying [25];

- mass share of dry soluble substances - by the refractometrric method [32].

At determining some components of the chemical composition for comparing results at storage, the content of substances was recalculated, readjusting for the mass loss. Natural mass losses were determined in percents of the initial mass. A sample was taken from storage, if natural mass losses reached $10 \%$ and products had signs of damages by diseases and physiological disorders. At the end of storage, the output of standard products was determined [9].

The structure of natural mass losses, physical properties (specific mass, physical porosity of heads) were determined by V. A. Koltunov [26].

The volume of cauliflower head was determined by immersing it in water in a measuring cylinder with further determining the volume of ejected water.

At forming a multi-factor dependency model of mass losses of cauliflower heads on weather conditions, storage duration, the linear function was used:

$$
\mathrm{Y}=\mathrm{a} 0+\mathrm{a}_{1} \mathrm{X}_{1}+{ }_{\mathrm{a}^{2}} \mathrm{X}+\ldots+\mathrm{a}_{\mathrm{n}} \mathrm{X}
$$

At analyzing and processing experimental data and prognosticating the final result, the methods of variation statistics were used: mathematical processing and plural correlation and regression analyzes were conducted [27], using the computer programs MS Office Excel 2007, package «Statistica $6 »$ and a personal computer.

\section{Results of studying the intensity of natural mass losses of cauliflower at storage}

Mass losses of cauliflower at the expanse of evaporation depending on weather conditions of vegetation period of plants were analyzed. It has been established, that there is a middle force reverse connection with the coefficient correlation $r=-0,465$ between the intensity of water evaporation at cauliflower heads storage and GTC (hydrothermal coefficient), middle force connection with the coefficient correlation $\mathrm{r}=0,437$ - with the average day temperature, and strong reverse connection $\mathrm{r}=-0,776$ with the relative air humidity respectively. There was elaborated the regression equation that gives an understanding about mass losses of cauliflower heads, packed in PF at the expanse of water evaporation in the following limits of thermal resources: sum of precipitation for the period with active temperatures $93,1-240,9 \mathrm{~mm}$; sum of active temperatures $1743,4-2544,3{ }^{\circ} \mathrm{C}$. 


$$
\mathrm{Y}=2,94+0,079 \mathrm{x}_{1}-0,038 \mathrm{x}_{2}-0,027 \mathrm{x}_{3},
$$

where $\mathrm{x}_{1}-\mathrm{GTC}, \mathrm{x}_{2}$ - average daily temperature, ${ }^{\circ} \mathrm{C} ; \mathrm{x}_{3}-$ air relative humidity, $\%$

In the experiments the moisture release of cauliflower heads, packed in PF, was $26,6-35,0 \%$ of the total mass loss at storage, in SF polyethylene packs - 16,8-23,4\%. Such difference may be explained by the fact that SP densely covers a fruit, creating an additional cover.

At storing fruits open, mass losses for moisture release were 88,4-90,5\% depending on sort. Heads of different sorts differ by condition of the external surface that may be a certain measure or barrier for the movement of water steam or evaporation surface that acts only if there is the continuous movement through the cytoplasm or cellular coat, where water moves towards the evaporation surface from its source. The surface of cauliflower heads consists of living cells, through which coat water penetrates. It penetrates through these cells with speed $0,17 \mathrm{mg} / \mathrm{cm}^{2} \mathrm{mbar}$ per year. The cuticle width varies depending on sort. But there is a general property, when the evaporation surface is at the distance no more than the width of one cellular wall from a water source. Thus, the way of water molecules that diffuse to the surface is very short, near $1 \mathrm{mcm}$. PP creates a strong barrier against moisture evaporation. The steam permeability that is the film ability to pass water steam is connected with natural mass losses. The water permeability of the film with width $0,04 \mathrm{~mm}$, used in the experiments is $0,035 \mathrm{~g} / \mathrm{dm}^{3}$ for 24 hours. So, the film almost doesn't permeate water steam, and the high humidity of the environment is fast created in the package at the expanse of moisture evaporation by products; it prevents its mass losses and fading.

At packing in the stretch-film (SF), the moisture decrease intensity in \% per day was least $0,30-0,31$. The ratio between moisture losses and ones of dry substances is $0,45-0,68$. At packing in PSF the moisture decrease intensity in \% per day was a bit higher $-0,37-0,43$.

In a hermetic package the oxygen content decreases and one of carbon dioxide increases at the expanse of respiration of products themselves, it favors the respiration intensity decrease, moisture release at respiration and losses of resource substances. Moisture evaporation depends not only on package type, but also on hybrid features

The intensity of water evaporation by cauliflower heads depends on their physical parameters: specific weight, volume and porosity. It has been established the correlation of the water evaporation intensity at cauliflower storage depending on its physical parameters: water evaporation intensity at storing cauliflower heads has the strong reverse connection with the specific weight of heads $\mathrm{r}=-0,8495$, middle reverse connection with their porosity $\mathrm{r}=-0,685$ and middle connection with their volume $r=0,589$.

There was elaborated the equation of regression of mass losses of cauliflower heads from the aforesaid parameters

$$
\mathrm{Y}=6,19-5,17 \mathrm{x}_{1}-0,001 \mathrm{x}_{2}-0,13 \mathrm{x}_{3},
$$

where $\mathrm{x}_{1}$ - specific weight, $\mathrm{g} / \mathrm{cm}^{3}, \mathrm{x}_{2}$ - head volume, $\mathrm{cm}^{3}, \mathrm{x}^{3}-$ head porosity, $\%$.

The way of cauliflower packing influences losses from microbiological spoilage. At storing in the performed stretch-film, first signs of diseases appeared at 30-40-th day, depending on hybrid. Losses in Kasper $\mathrm{F}_{1}$, Satamaria $\mathrm{F}_{1}$ and Skywoker $\mathrm{F}_{1}$ at 70 -th day of storage were 10,0 \%, $9,8 \%$ and $10,4 \%$ respectively

The more storage duration of cauliflower of late ripeness was provided by individual packing of heads in a polyethylene stretch-film. This packing type provided less total natural losses of products: in Skywoker $F_{1}-6,0 \%$, in Kasper $F_{1}$ and Santamaria $F_{1}-6,3 \%$. Natural losses for a day in variants with using a stretch-film were within $0,05-0,06 \%$ depending on hydrid.

\section{Conclusions}

1. Cauliflower mass losses at the expanse of water evaporation depend on weather conditions of the vegetation period of the plant. It has been established, that there is a middle force reverse connection with the coefficient correlation $r=-0,465$ between the intensity of water evaporation at cauliflower heads storage and GTC, middle force connection with the coefficient correlation 
$\mathrm{r}=0,437$ with the average day temperature, and strong reverse connection $\mathrm{r}=-0,776$ with the relative air humidity. There was elaborated the regression equation that gives an understanding about mass losses of cauliflower heads, packed in PF at the expanse of water evaporation.

2. The intensity of water evaporation of cauliflower at storage depends on package method. At packing in a stretch-film /9SF), the intensity of moisture decease, $\%$ a day, was the least, equal to $0,30-0,31$. The ratio between moisture losses to ones of dry substances is $0,45-0,68$. At packing in a performed stretch-film (PSF), the intensity of moisture decrease, \% a day, was higher a little $-0,37-0,43$.

3. The more storage duration of cauliflower of late ripeness was provided by individual packing of heads in a polyethylene stretch-film. This packing type provided less total natural losses of products: in Skywoker $F_{1}-6,0 \%$, in Kasper $F_{1}$ and Santamaria $F_{1}-6,3 \%$. Natural losses for a day in variants with using a stretch-film were within $0,05-0,06 \%$ depending on hydrid.

Such researches were already conducted for broccoli and are their continuation. Further promising research directions are to combine studies of the influence of weather condition of the vegetation period of Brussels sprouts on their storage quality.

\section{References}

[1] Vegetable Farming Techniques Manual. Available at: https://www.jica.go.jp/nepal/english/office/others/c8h0vm0000bjww96-att/tm_2.pdf

[2] Bolotskih, A. S. (2002). Kapusta. Kharkiv: Folio, 320.

[3] Lipinski, B., Hanson, C., Lomax, J., Kitinoja, L., Waite, R., Searchinger, T. (2013). Reducing food loss and waste. World Resources Institute, Washington.

[4] Kiaya, V. (2014). Post-Harvest losses and strategies to reduce them. Technical paper on Post-Harvest Losses. ACF, 25. Available at: https:/www.actioncontrelafaim.org/wp-content/uploads/2018/01/technical_paper_phl__.pdf

[5] Bovi, G. G., Caleb, O. J., Linke, M., Rauh, C., Mahajan, P. V. (2016). Transpiration and moisture evolution in packaged fresh horticultural produce and the role of integrated mathematical models: A review. Biosystems Engineering, 150, 24-39. doi: https://doi.org/10.1016/j.biosystemseng.2016.07.013

[6] Mahajan, P., Rux, G., Caleb, O., Linke, M., Herppich, W., Geyer, M. (2016). Mathematical model for transpiration rate at $100 \%$ humidity for designing modified humidity packaging. Acta Horticulturae, 1141, 269-274. doi: https://doi.org/10.17660/actahortic.2016.1141.33

[7] Koval, A. (2005). Effektivnaya upakovka svezhey plodoovoshchnoy produkcii. APK-Inform: ovoshchi \& frukty. Available at: https://www.fruit-inform.com/ru/technology/pack/32770\#.XIuiiSIzaG4

[8] Jacobsson, A., Nielsen, T., Sjöholm, I., Wendin, K. (2004). Influence of packaging material and storage condition on the sensory quality of broccoli. Food Quality and Preference, 15 (4), 301-310. doi: https:// doi.org/10.1016/s0950-3293(03)00070-3

[9] Annelie, J. (2004). Quality aspects of modified atmosphere packaged Broccoli. Lund University Publications, 98-102.

[10] Lucera, A., Costa, C., Mastromatteo, M., Conte, A., Del Nobile, M. A. (2011). Fresh-cut broccoli florets shelf-life as affected by packaging film mass transport properties. Journal of Food Engineering, 102 (2), 122-129. doi: https://doi.org/10.1016/j.jfoodeng.2010.08.004

[11] Viña, S. Z., Mugridge, A., García, M. A., Ferreyra, R. M., Martino, M. N., Chaves, A. R., Zaritzky, N. E. (2007). Effects of polyvinylchloride films and edible starch coatings on quality aspects of refrigerated Brussels sprouts. Food Chemistry, 103 (3), 701-709. doi: https://doi.org/10.1016/j.foodchem.2006.09.010

[12] Bondarenko, H. L., Yakovenko, K. I. (Eds.) (2001). Metodyka doslidnoi spravy v ovochivnytstvi i bashtannytstvi. Kharkiv: Osnova, 368.

[13] Derzhavnyi reiestr sortiv roslyn prydatnykh dlia poshyrennia v Ukraini na 2015 rik (stanom na 14.01.2015 roku) (2015). Kyiv, 324. Available at: https://www.twirpx.com/file/1613940/

[14] Standart EEK OON FFV-11, kasayushchiysya sbyta i kontrolya tovarnogo kachestva cvetnoy kapusty (2017). New York, Geneva.

[15] DSTU 3280-95. Kapusta tsvitna svizha. Tekhnichni umovy (1995). Kyiv: Derzhstandart Ukrainy, 30. Available at: https://www.twirpx.com/file/1935211/ 
[16] Dzheneev, S. Yu., Ivanchenko, V. I., Dzheneeva, E. L. (1998). Metodicheskie rekomendacii po hraneniyu plodov, ovoshchey i vinograda (organizaciya i provedenie issledovaniy). Yalta: Institut vinograda i vina «Magarach», 152.

[17] DSTU 4971:2008. Yashchiki polimernye mnogooborotnye dlya ovoshchey i fruktov. Tekhnicheskie usloviya (2008). Gosudarstvennyy Standart Ukrainy.

[18] GOST 10354-82. Tekhnicheskie usloviya. Plenka polietilenovaya (2007). Moscow, 23.

[19] DSTU ISO 874-2002. Frukty ta ovochi svizhi. Vidbir prob (2002). Derzhstandartu Ukrainy. Available at: http://document.ua/frukti-ta-ovochi-svizhi.-vidbir-prob-iso-874-1980-idt--std9056.html

[20] Naichenko, V. M., Zamorska, I. L. (2010). Tekhnolohiya zberihannia i pererobky plodiv ta ovochiv. Uman: Sochinskyi, 327.

[21] Kataloh nasinnia ovochevykh kultur Beio Zaden. Available at: http://www.bejo.ua/

[22] Chto takoe polietilen? Available at: http://itapro.com.ua/pe

[23] DSTU ISO 751:2004. Produkty pereroblennia fruktiv i ovochiv. Metod vyznachennia sukhykh rechovyn, ne rozchynnykh u vodi (kontrolnyi metod) (2005). Kyiv, 8.

[24] DSTU ISO 2173:2007. Produkty z fruktiv ta ovochiv. Vyznachennia rozchynnykh sukhykh rechovyn refraktometrychnym metodom (2009). Kyiv, 11.

[25] Koltunov, V. A. (2002). Prohnozuvannia zberezhennia yakosti prodovolchykh tovariv. Kyiv, 198.

[26] Dospekhov, B. A. (1985). Metodika polevogo opyta (s osnovami statisticheskoy obrabotki rezul'tatov issledovaniya). Moscow: Agropromizdat, 351. 